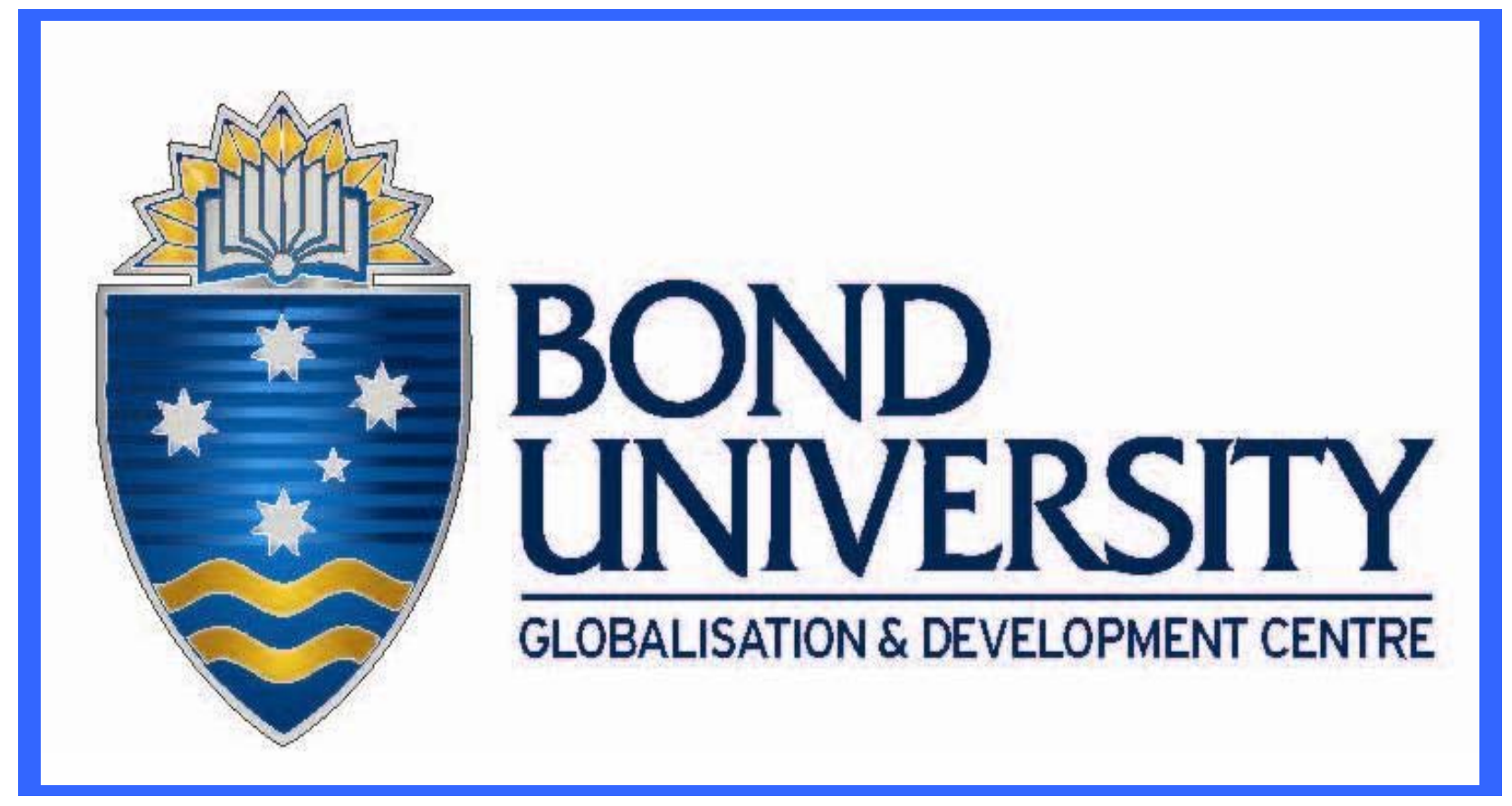

Rosita Dellios

Nadir Kemal Yilmaz

\title{
SINO-TURKISH RELATIONS IN A GLOBALISING ASIA-PACIFIC
}

No. 24, October 2008 


\begin{abstract}
Relations between China and Turkey are quiescent. In a globalizing Asia-Pacific, however, they are unlikely to remain so. High economic interdependence in the presence of the rise of Asian and Eurasian powers suggest that China and Turkey as multiregional states have a common interest in regional cooperation. It is within this context that bilateral relations are likely to develop. China's rapid rise means that its impact will not be confined to Pacific Asia. Increasingly, with the quest for energy security, China is setting its diplomatic compass westward to Eurasia and the Middle East. With Russia - another multiregional state - proving itself a keen player in the energy sphere and its own geopolitical neighborhood, an intersection of interests will become more clearly discernible. Coming from different though not necessarily oppositional strategic camps, the Shanghai Cooperation Organization (SCO) and the North Atlantic Treaty Organization (NATO), China and Turkey are well positioned at the eastern and western gates of Eurasia to frame a cooperative regionalism with global properties. The alternative would be a collision of interests with global repercussions. Thus the regional setting for bilateral relations provides the key to the future of Sino-Turkish relations. The theoretical perspective that best explains the development of Eurasia as a region of mutually constitutive relationships is social constructivism. This theoretical perspective accords with both Chinese and Turkish thought systems and the impact of global norm-building.
\end{abstract}




\section{Sino-Turkish Relations in a Globalizing Asia-Pacific}

\section{Introduction}

Ten thousand kilometers and decades of neglect separate the People's Republic of China and the Republic of Turkey. Standing as they do at the eastern and western gateways to the energyrich Eurasian continent, it is surprising that they have not been brought closer together by the economic, security and governance imperatives of the prevailing global era. Diagnosing the problem of a relationship that has been described by one analyst as "formal but distant" 1 and by another as not making progress, ${ }^{2}$ is no simple undertaking. Despite the establishment of formal relations in 1971, Turkey's importance to China is still relatively low compared to China's more focused relations with oil-rich Middle Eastern states like Saudi Arabia and Iran. In a similar vein, China has traditionally been overlooked by Ankara in favor of the European Union (EU) and the North Atlantic Treaty Organization (NATO). Not surprisingly in this absence of mutual regard, which was not helped by the preceding Cold War ideological divide, the literature on ChinaTurkey relations is scant. The quest to understand the relationship is largely confined to the rhetoric of diplomacy, news reports, an official website on trade relations, and reports in think tanks. ${ }^{3}$ This paper seeks to examine relations between Beijing and Ankara within the wider context of a globalizing Asia-Pacific in an effort to understand the dynamics that are forging closer ties, even if

\footnotetext{
${ }^{1}$ John K. C. Daly, “Sino-Turkish Relations Beyond the Silk Road”, China Brief, The Jamestown Foundation, Vol. 7, No. 4 (February, 2007), available at http://www.jamestown.org/publications_details.php?volume_id=422\&issue_id $=4012$ \&article i $\mathrm{d}=2371932$, accessed 19.12.07. For more in-depth analysis of Sino-Turkish economic relations, see "TurkishChinese Political Relations”, Chinacircle.biz, 3 March 2008, http://www.chinacircle.biz/turkey-chinapolitical-relations/turkish-chinese-political-relations, accessed 12.9.08; Nadir Kemal Yilmaz, Fang Lee Cooke, and Rosita Dellios, “Turkey’s FDI Policy and Chinese Foreign Direct Investments in Turkey: Some Economic and Management Implications”, Global Business Review, Vol. 9, No. 1, April/May 2008; and Rosita Dellios and Nadir Kemal Yilmaz, "Turkey and China: A Study in Symmetry", Journal of Middle Eastern and Islamic Studies (in Asia), Vol. 2, No. 1, 2008, pp. 13-30, http://www.sh-mideast.cn/pdf/08113-30..pdf.

2 'Turkish-Chinese Political Relations', Chinacircle.biz, 3 March 2008, http://www. chinacircle.biz/turkeychina-political-relations/turkish-chinese-political-relations, accessed 12.9.08

${ }^{3}$ These are exemplified in the following: “China, Turkey Signed Joint Communique”, People's Daily, 20 April 2000, available at http://english.peopledaily.com.cn/english/200004/20/eng20000420 39289.html, accessed 19.12.07; Suna Lee, “Turkey and China - Strengthening Economic Ties”, ASAM, 2007, available at http://www.asam.org.tr/tr/yazigoster.asp?I D=1844\&kat1=8\&kat2=

accessed 19.12.07; Anatolian News Agency, “Reinforcing Relations between Turkey, China”, Turkish Daily News, 28 November 2007, available at http://www.turkishdailynews.com.tr/article.php?enewsid=89789, accessed 19.12.07; and Turkey-China Economic \& Trade Cooperation, official website, http://www.ctc.mofcom.gov.cn/ciweb/tcc/index.jsp, accessed 1.12.07. On think tanks, besides Jamestown Foundation in the US, there are the Ankara-based International Strategic Research Organization (ISRO - USAK) at www.usak.org.tr, and the Center for Shanghai Cooperation Organization (SCO) Studies within the Shanghai Academy of Social Sciences at www.coscos.org.cn.
} 
these are not fully apparent at present. It will also identify the obstacles that are retarding the process, from a perceived divergence of interests to ethnic politics. The paper will conclude with prospects for the future and recommendations for stronger regionally-based cooperation.

\section{Earlier Forms of Sino-Turkic Cooperation}

Relations between the two nations have not always languished across the Eurasian divide. Far from it, their interaction through the continental trade routes known as the Silk Road produced a rich historical tapestry of interaction. From the second century BC through to the 15th Century, the Silk Road - so named because silk was at first the main commodity traded - linked the continents of Asia and Europe. Caravans transported Chinese silk and other luxury goods from the Chinese imperial capital of Chang'an (Xi'an) to the Eastern capital of the Christian world, Constantinople. Renamed Istanbul under the Ottoman Turks, the city continued as a political, economic and cultural hub. Traveling east, the caravans conveyed cosmetics, amber, carpets and other products. With commerce came exchanges of religious culture (from Buddhism to Islam) and technology (such as the production of paper and glass).

Moreover, the East-West trade routes carried political ramifications with attempts to unify the region resulting in inter-ethnic royal bloodlines and pragmatism in civilization crossovers. Thus it is notable that the Tang (AD 618-906) imperial family came from Turko-Mongol ancestry through the Toba tribe of Central Asia. The Toba founded the Northern Wei dynasty in AD 386, reunifying northern China above the Yangze River, and extending dynastic control across the northern steppes, the Tarim Basin, and the North China Plain. ${ }^{4}$ Sino-Turkic families not only formed the ruling elites in the Tang, but deployed a multinational army to back China's political power over part of the Silk Road. ${ }^{5}$ While highly Sinicized, the Tang privately maintained their language and customs. It was understandable that the "foreign” rulers should adopt Chinese

\footnotetext{
4 See Edmund Capon and Werner Forman, Tang China: Vision and Splendour of a Golden Age, Macdonald Orbis, London, 1989, p. 14; and Edwin O. Reischauer and John K. Fairbank, East Asia: The Great Tradition, 8th edn, Houghton Miffin Company, Boston, 1970, pp. 154-155.

${ }^{5}$ Charles Holcombe, In The Shadow of the Han: Literati Thought and Society at the Beginning of the Southern Dynasties, University of Hawaii Press, Honolulu, 2004, p. 139; and Joanna Waley-Cohen, The Sextants of Beijing: Global Currents in Chinese History, W.W. Norton \& Co Waley-Cohen, New York, 1999, p. 23.
} 
administrative culture, which was drawn from Confucian learning, in order to maintain so large an empire and retain the Mandate of Heaven (the legitimacy of the time) to rule. The Sui dynasty (581-618) that came before the Tang was founded by Yang Jian, of Sino-Turkic ancestry through his family links to the Northern Zhou ruling family. ${ }^{6}$

The first use of "Turk" as a political name, and henceforth as a designation (Turkic) for a linguistic group, was Tujue in the sixth century. The Tujue (or Göktürk) lived in the northern part of presentday Xinjiang in Northwest China and expanded their empire across Eurasia as far as Eastern Europe and North Asia. The area, often referred to as Turkistan, was conquered by the Mongols under Genghis Khan in 1220. By 1279, the Mongols conquered China as well, ruling for 89 years as the Yuan dynasty. Today, after the expansion of Tsarist Russia and, subsequently, the Soviet Union, Turkic culture has survived in its local variations. Five Central Asian states Azerbaijan, Kazakhstan, Kyrgyzstan, Turkmenistan, and Uzbekistan - are identifiably Turkic in culture, though the region as a whole is regarded as culturally diverse. Turkic culture is also found in China’s Xinjiang Uyghur Autonomous Region. This eastern part of “Turkistan” (hence the name “East Turkistan” or “Chinese Turkistan”) was conquered by China’s Manchu rulers, who formed the Qing dynasty (1644-1912), and was given the name Xinjiang - meaning “new frontier” - when incorporated into the Chinese polity.

\section{A Comparative Profile of the Two Republics through the Prisms of Theory and Culture}

Today, the modern states of China and Turkey present an intriguing couple. A conference paper for the International Studies Association on poliheuristic theory - which seeks to explain foreign policy decision-making by observing it in two stages, cognitive and rational - employs Turkey and China as case studies. ${ }^{7}$ Why? They are seen as "two important states that frequently are characterized as sui generis” and show distinctive peculiarities. China's peculiarity is that it cannot be analyzed purely on the basis of "Western rationality, with its cost-benefit analysis" as it is

\footnotetext{
${ }_{7}^{6}$ Capon and Forman, Tang China, p. 14.

7 Nukhet Sandal, Enyu Zhang, Carolyn C. James, and Patrick James, "Poliheuristic Theory in Comparative Perspective: Theory and Evidence for Turkey and China”, unpublished conference paper, International Studies Association Conference, San Diego CA, March 2006, available at http://www.allacademic.com/meta/p100451_index.html, accessed 19.12.07.
} 
grounded in a different philosophical system; hence “cognitive heuristics” have an important role to play in analyzing Chinese foreign policy-making. Turkey’s peculiarity is that, as with China, its unique (sui generis) status means that it will "resist the predictions of models based on Western, social scientific concepts". 8 This also permits greater scope for the application of "cognitive heuristics”. What is unique about Turkey? The authors of the study on poliheuristic theory have noted a number of distinctive features, including: its democratic, secular profile in a volatile region; its capacity to absorb several military coups and bounce back as a constitutionally-based democracy; its religious but generally not ethnic ties with the Middle East; its pro-Western strategic affiliation during the Cold War; and even its continuing sound relations with Israel, a situation which is deemed remarkable for a predominantly Muslim country. ${ }^{9}$

If social constructivism is introduced as the theoretical framework, the emphasis falls not on the unique but on the mutable: a nation's identity is seen as being a work-in-progress through mutual interaction and norm formation. Thus the constructions to which the theory refers are those of shared meanings obtained through social learning. As Shimko defines it, social constructivism is a "perspective that stresses the importance of identities and shared understandings in shaping the behavior of social actors”. ${ }^{10}$ Kegley and Wittkopf further elaborate by defining it as:

A liberal-realist theoretical approach advocated by Alexander Wendt that sees self-interested states as the key actors in world politics; their actions are determined not by anarchy but by the ways states socially "construct" and then respond to the meanings they give to power politics, so that as their definitions change, cooperative practices can evolve. ${ }^{11}$

Social constructivism is the preferred theory through which international relations scholars in China seek to explain China's role in the world. ${ }^{12}$ This makes sense in view of the theory's willingness to (a) incorporate the influences of history and culture (or those unique elements calling forth the use of “cognitive heuristics”, noted above); and (b) its affinity with the Chinese

\footnotetext{
${ }^{8}$ Ibid.

${ }^{9}$ Ibid. See also Bulent Aras and Rabia Karakaya Polat, "Turkey and the Middle East: Frontiers of the New Geographic Imagination”, Australian Journal of International Affairs, Vo. 61, No. 4, December 2007, pp. 471-488.

${ }^{10}$ Keith L. Shimko, International Relations: Perspectives and Controversies, Houghton Mifflin, Boston, 2005, p. 63.

${ }^{11}$ Charles W. Kegley, Jr and Eugene R. Wittkopf, World Politics: Trend and Transformation, St. Martin's, New York, 2004, p. 52.

${ }^{12}$ This is according to Peking University's professor of diplomacy, Zhang Qingmin, interview with Rosita Dellios, Beijing, 5 December 2007; and Qin Yaqing, a constructivist theorist, who is vice president and professor on international studies at China Foreign Affairs University, discussed at a seminar attended by Rosita Dellios, Beijing, 23 June 2008.
} 
theory of correlativity in which the parties of a relationship make the necessary conditions for being what they are, for example, teacher and student. It is a condition, as Hall and Ames put it, of "each requiring the other for adequate articulation”. ${ }^{13}$ Such correlativity accords with the yin-yang philosophy of interactive, and hence dynamic, difference and balance within the whole.

In Turkey’s case, the cultural equivalent to yin-yang correlativity may be found in Sufism. This mystical expression of Islam relates to the mainstream religion as a counterculture, much like Daoism has been regarded as the countercultural yin to the Confucian yang. The popularly termed “whirling dervishes” of Turkey come from a Sufi brotherhood known as the Mevlevi, named after its founder, Mevlana (Jalal ad Din Rumi, d. 1273). The whirling is a spiritual practice designed to achieve mystical union with God. While different thought systems prevail in Turkish and Chinese culture, yet beneath their difference there is an underlying ontological agreement. Both were concerned with the direct experience (an "intuitive and experiential knowing”14) of God, or in the case of the Chinese system, the Dao (the Way). As stated in the opening of the classical Daoist text, the Dao De Jing (The Book of the Way and Its Power):

The Way that can be spoken of is not the constant Way;

The name that can be named is not the constant name.

The nameless is the beginning of Heaven and Earth;

The named is the mother of all things.

In a comparative study of Sufism and Daoism, it was found that the two systems were in agreement on a number of points despite one deriving from Islamic philosophy and the other from Chinese. These points of agreement include the view of reality conveyed by the Dao De Jing above. It is an awareness of "a higher ontological level where all things are deprived of their seemingly solid essential boundaries and disclose their natural amorphousness”. ${ }^{15}$

\footnotetext{
${ }^{13}$ David L. Hall and Roger T. Ames, Thinking Through Confucius, State University of New York, N.Y, 1987, p. 17.

${ }^{14}$ Franklin D. Lewis, Rumi: Past and Present, East and West, Oneworld, Oxford, 2003, p.24.

15 Toshihiko Izutsu, Sufism and Taoism: A Comparative Study of Key Philosophical Concepts, University of California Press, Berkeley, 1983, p. 480.
} 
A recognition that both nations' identity is a social construction which depends on their interactions with others, and which brings to bear traditional systems of thought within this interaction, is of interest when positioned within the seemingly amorphous world of globalization, with its compression of time and space. Here China and Turkey possess the philosophical disposition and historical experience to adapt capably to globalization's offspring, regionalism. This is a regionalism with global characteristics and through which the nation-state pursues its interests. ${ }^{16}$ In the case of the European Union, the global region is so advanced that states pool their sovereignty and the unit of analysis is shifting from state to region. The disabling features of a regionally-enabled proximity, when an EU-level of integration is still unrealized, are often those of unresolved ethnic or boundary issues, as well as a clash of economic interests.

\section{Clash of Economic Interests and the New Geopolitics}

The region which represents the common ground of Sino-Turkish history and future opportunities is Eurasia. Encompassing the Caspian Sea basin and Central Asia, it represents one of the world's richest, largely untapped, sources of oil and natural gas. Here China and Turkey have been viewed to be in competition over resources:

The rivalry is particularly pronounced in the struggle for Caspian exports of gas and oil from the former Soviet states ringing the inland sea, whose reserves contain an estimated 32 billion to 220 billion barrels of recoverable oil. Turkey scored an initial demarche in Azerbaijan with the May 2006 opening of the 1,092-mile-long, \$3.6 billion, Baku-Tbilisi-Ceyhan pipeline, capable of handling one million barrels per day ...

China, however, has made significant inroads in Kazakhstan. . . . In November 2005, a $\$ 700$ million, 600 mile-long Kazakhstan-China pipeline with an annual capacity of 20 million barrels became operational—oil that otherwise might have flowed westwards . . . China has similarly trumped Turkey in Turkmenistan ... [where China] would receive up to 30 billion cubic meters of

\footnotetext{
${ }^{16}$ See He Kai, "Reining in the Dragon: Multilateral Institutions and China's Peaceful Rise”, conference paper, International Studies Association 48th Annual Convention, Chicago, USA, February 2007, http://www. allacademic.com/meta/p179965_index.html, accessed 5.7.08.
} 
natural gas annually from the still undeveloped Yuzhny Iolotan field via a pipeline to be constructed across Kazakhstan. ${ }^{17}$

If there is an East-West resource rivalry - be it China-Turkey or Russia-US - then the aftermath of the Russo-Georgian war of August 2008 has both accentuated and changed the dynamics. It has accentuated it because of heightened suspicion between Russia and US-NATO but changed the dynamics to relation to Beijing. Not only has Moscow alarmed its neighbors by using military means to promote its interests, but it has improved China's image compared to Russia's. This is likely to be noted not only by smaller states on China's periphery, but is also of consequence in big power relations. Beijing has been provided with the opportunity to advance its own interests with both Washington and Moscow; however the strategic triangle of the Cold War in which the 'China card' was played is unlikely to repeat itself in the current global modality of complex interdependence. "Rather," as Jing Huang points out, "China could be held hostage by both sides, as China needs markets, capital and technology from the West, while it has a growing appetite for Russian energy and other commodities.” ${ }^{18}$ It is therefore a strategic imperative and not only an act of responsible governance that China will continue to champion greater regional cooperation and integration in Central Asia - where the Shanghai Cooperation Organization (SCO) is proving effective - and further its engagement in transregional cooperation to offset polarization between East and West. It is in this respect that stronger ties with Turkey, a NATO member and EU aspirant, will play a strategic role.

Sino-Turkish economic and trade relations are an important input in the geostrategic calculus and likely to take the lead in establishing greater mutual familiarity. Trade between China and Turkey has experienced a sixfold increase in the last half decade. ${ }^{19}$ In the decade 1996-2006, the increase was 15-fold. According to the Turkish Ministry of Foreign Trade figures, total imports and exports reached US\$10.4 billion in 2006. If growth rates continue as projected, with an average

\footnotetext{
${ }^{17}$ Daly, "Sino-Turkish Relations Beyond the Silk Road”.

18 “Anxious Neighbours”, Strategic Comments, International Institute for Strategic Studies, Vol. 14, Issue 7, September 2008, http:// www.iiss.org/publications/strategic-comments/past-issues/volume-142008/volume-14-issue-7/anxious-neighbours, accessed 17.9.08; and Jing Huang, "Beijing's Perspective on the Russo-Georgian Conflict: Dilemma and Choices", China Brief, The Jamestown Foundation, Vol. 8, Issue 17, 3 September 2008, p. 6.

19 Suna Lee, "Turkey and China - Strengthening Economic Ties”, ASAM, 8 November 2007, http://www. asam.org.tr/tr/yazigoster.asp?| D=1844\&kat1=8\&kat2=, accessed 19.12.07.
} 
of 50\% growth for China and 20\% for EU, Turkey’s trade volume with China will rise to half of its trade volume with the EU in 2010.

Problematic for Turkey is China's low-cost export advantage: the trade deficit accounted for $14 \%$ of Turkey's total trade deficit in 2006. This discrepancy is explained by the fact that twothirds of Turkey's imports that include machinery, fossil fuels, and electronics derive from China. ${ }^{20}$ Turkey’s exports are too narrowly concentrated in a few sectors - chromium, iron and steel, marble and granite - which account for over half its China-bound exports. ${ }^{21}$ The establishment of the Turkish trade office in Shanghai was a recognition of the need to diversify and acquire greater market familiarity. Turkish business people will be encouraged by China being ranked as a top 10 performer in the World Bank’s 2006 ranking on the Ease of Doing Business. Moreover, China has revamped its tax incentives to promote the higher end exports. ${ }^{22}$

China often proclaims its intention is to promote a "win-win" strategy in its economic dealings with its business partners. This also carries over to diplomacy and is intended to quell fears that China may develop into an intimidating regional presence. Fear of China and hedging strategies by significant others like the USA may be seen as part of the interactive, correlative operations of social constructivism. China does not want to be viewed as an emerging threat and those who perceive China as a threat do not wish this either. Thus in September 2005, US Deputy Secretary of State Robert Zoellick announced: "We now need to inspire China to become a responsible stakeholder in the international system." ${ }^{23}$ At the same time, Washington reserved the right to hedge against Beijing's hegemonic possibilities. The US government, through the Executive Summary of its Annual Report to Congress on The Military Power of the People's Republic of China, 2007, stated that:

The United States welcomes the rise of a peaceful and prosperous China, and it encourages China to participate as a responsible international stakeholder by taking on a greater share of responsibility for

\footnotetext{
${ }^{20}$ Anatolian News Agency, “Reinforcing Relations between Turkey, China”, Turkish Daily News, 28 November 2007, http://www.turkishdailynews.com.tr/article.php?enewsid=89789, accessed 19.12.07.

21 Lee, “Turkey and China - Strengthening Economic Ties".

22 For details, see Turkey-China Economic \& Trade Cooperation, official website, http://www.ctc. mofcom.gov.cn/ciweb/tcc/index.jsp, accessed 1.12.07.

${ }^{23}$ See Xinhua, “New Vocabulary Ushers China-US Relations into Global Scenarios”, People’s Daily Online, 22 December 2005, http://english. people.com.cn/200512/22/print20051222_229941. html, accessed 12.11.06.
} 
the health and success of the global system. However, much uncertainty surrounds the future course China's leaders will set for their country, including in the area of China's expanding military power and how that power might be used . . . China’s actions in certain areas increasingly appear inconsistent with its declaratory policies. Actual Chinese defense expenditures remain far above officially disclosed figures. This lack of transparency in China's military affairs will naturally and understandably prompt international responses that hedge against the unknown. ${ }^{24}$

In light of this it is not surprising that Chinese strategy favors deploying the trader over the warrior, a situation which is not only correlative with its international environment but also in keeping with a strategic culture which privileges wen (civility) over wu (martiality). $W u$ was only to be resorted to if wen failed and was believed to be most effective when it was not dominant over wen. Thus China's work-in-progress identification of itself in 2004 as rising peacefully (heping jueqi) was refined to peaceful development to further alleviate threat perceptions associated with China's growth. In October 2005, PRC President Hu Jintao, articulated China's foreign policy goals of a 'harmonious world' (hexie shijie), identifying this as the primary condition for peace and development in international relations. The following year of 2006 was the first in which China implemented its "harmonious world-oriented" diplomacy which took into account "both its national interests and the interests of other countries". ${ }^{25}$ This "win-win" strategy was met, as shown above, with a dual response from the US - encouragement to Beijing to integrate with the world responsibly but also a preparedness by the US to deal with a China that may become foe rather than friend. In this respect the role of Turkey can be a productive one. In a reversal of the old realist adage of "my enemy's enemy is my friend”, Turkey could represent a constructivist motto of “my potential enemy’s friend should be my engaged ally”. This broadening and thickening of relationships allows for greater trust-building across the regional domain of mutual interest.

Like China, Turkey is still a developing country. Despite urban pockets of $21^{\text {st }}$ century sophistication, it must address huge domestic priorities in economic development. Moreover, concern over internal security issues (elaborated below) has taken precedence over possible aspirations for regional leadership. Ankara’s post-Cold War “new activism” has been noted with

\footnotetext{
${ }^{24}$ Office of the US Secretary of Defense, Annual Report to Congress: The Military Power of the People's Republic of China, 2007, http://www.defenselink.mil/pubs/pdfs/070523-China-Military-Power-final.pdf, accessed 3.3.08.

${ }^{25}$ Yan Xuetong, "China's First Step Forward in Its 'Harmonious World-Oriented' Diplomacy”, People's Daily Online, 19 December 2006, http://english.peopledaily.com.cn/200612/19/eng20061219 333955. html, accessed 20.9.08.
} 
regard to the Middle East, ${ }^{26}$ but this falls short of any hegemonic ambition within that volatile region, let alone Eurasia, where Russia is clearly more influential. Rather, Ankara has long displayed its Western strategic orientation through membership of NATO. In the post-Cold War era, its civil-economic role was highlighted through acceptance as a candidate for EU membership at the Helsinki Summit in 1999. Accession negotiations were opened in 2005. The prospect of membership deepened structural reforms in the economy and the democratization process. ${ }^{27}$ Just as United Nations and World Trade Organization (WTO) membership gave China the legitimating international credentials it so assiduously pursued, so too acceptance into the EU would represent “the crowning achievement of Turkey's long and painful modernization efforts”. ${ }^{28}$ These efforts began in the late $19^{\text {th }}$ century when "Istanbul launched one of the earliest modernization projects in history" and when the Ottoman military adopted Western equipment and professional education. ${ }^{29}$ A more radical Westernization took root with the establishment of the Republic of Turkey under the leadership of Mustafa Kemal Atatürk in the early $20^{\text {th }}$ century. In the $21^{\text {st }}$ century, disillusionment with the pace of EU accession and American foreign policy - especially after the invasion of Iraq - does not suggest an abandonment of the West. Rather, it is an expression of Turkey’s awareness of its post-Cold War interests as a multiregional state facing the Balkans, the eastern Mediterranean, the Caucasus, Central Asia and the Middle East.

\section{The Quest for Security through Regional Cooperation}

The transformation of China and Turkey in global history has seen them move from empires to modern nation-states to cultivators of multilateral institutions that enhance their world standing. Not only is reputation at stake but the existential issue of state security. It is well to remember that both countries regard religious extremism, separatism and terrorism as priority security issues. On this basis, Turkey's military has engaged in cross border raids against the Kurdistan Workers' Party (PKK) members based in Northern Iraq. In addition to seeking to curtail

\footnotetext{
${ }^{26}$ See Stephen Larrabee, “Turkey Rediscovers the Middle East”, Foreign Affairs, Vol. 86, No. 4, pp. 103-114.

27 See Commission of the European Communities, Turkey 2006 Progress Report, Brussels, 8 November 2006, available http://ec.europa.eu/enlargement/pdf/key_documents/2006/nov/tr_sec 1390 en.pdf, accessed 23.12.07.

${ }^{28}$ Aras and Polat, “Turkey and the Middle East: Frontiers of the New Geographic Imagination”, p. 473.

${ }^{29}$ Ömer Taspinar, “The Old Turks' Revolt: When Radical Secularism Endangers Democracy”, Foreign Affairs, Vol. 86, No. 6, November/December 2007, pp. 116-7.
} 
attacks on its population, Ankara upholds the key foreign policy principle of territorial unity and integrity. This is not only a principle it applies to itself, but also to other nation-states, including China and Iraq. "Peace at home, peace in the world” is Ankara's policy slogan for this position. The "One China” policy is also an expression of determination to prevent separatists from "splitting” the "motherland". Beijing has threatened military action against Taiwan if the island declares formal independence; and it maintains tight security against Tibetan and Uyghur independence movements. Its fears of attempts by these groups to draw attention to their cause during the 2008 Beijing Olympics were justified: Tibetan protests broke out during the prelude to the Olympics. The international Olympic torch relay attracted pro-Tibetan protestors worldwide. Three attacks by Uyghur separatists resulted in the killing of more than 30 people in Xinjiang. While the Olympic Games themselves were not disrupted, and while China was able to impress the world with the soft power equivalent of "shock and awe" at the opening ceremony, ${ }^{30}$ it was inevitable that a high-profile event in a non-liberal country like China would be used to draw attention to dissident causes.

Ironically, one of the obstacles to better communication between China and Turkey is the historical background to some of their domestic fears: Maoists among the Kurds of Turkey and Turkic Uyghurs among the secessionists of China’s Northwest. Turkey, after all, had outlawed the formerly Maoist PKK, and China distrusts the Turkic Uyghurs who have long regarded Turkey as their ethnic homeland. Today neither country gives support to anti-government elements in the other. However the potential energy gains for China in Northern Iraq might stir future concern in Turkey. The state-controlled China National Petroleum Corporation secured an agreement in September 2008 to exploit an Iraqi oil field south of Baghdad, while further developments are expected as Chinese were exploring “vast tracts in the country's Kurdish north”. ${ }^{1}$ Kurdish separatist aspirations for the creation of an independent Kurdistan - a situation which has "gained momentum” with the Iraqi Kurds ${ }^{32}$ - coupled with the prospect of Chinese dominance in its oil industry is a recipe for Sino-Turkish discord. This would be exacerbated in the event that Beijing

\footnotetext{
30 Fergus Hansen (“Less than Meets the Eye”, The Diplomat, September/October 2008) noted: “The opening ceremony of the Beijing Olympics was public diplomacy 'shock and awe'. It was intended to announce to the world China's return to centre stage and to vindicate in the eyes of the Chinese people its model of economic freedom combined with political constraint” (http://www.the- diplomat. com/article. aspx?aeid=8713, accessed 1.10.08).

31 Damien McElroy, “China Clinches First Iraq Oil Deal”, The Age (Melbourne), 9 September 2008, p. 10.

32 See analysis in Larrabee, “Turkey Rediscovers the Middle East”.
} 
vies with Taipei to recognize the new nation first. This hypothetical scenario is not improbable but clearly does not accord with the message that came out of SCO’s Dushanbe Declaration of 2008 to which China was strongly committed (see below). Already China has more oil personnel in Iraq than the US. ${ }^{33}$ How do the Chinese explain their presence in Iraq? The response is framed in cooperative 'win-win' terms rather than realist national interest rhetoric, though China's energy needs are the driving factor. This is evident in a statement made by Chao Shu-he, the chief geologist of an oil exploration team from China. "The Chinese have opened the door to cooperation,” he said. “China is more and more developed and it's our patriotic duty to contribute to development, even if we are far from home.”34

Even at home, in China's northwest, there is an effort to develop the region which is blessed with energy resources but disturbed by secessionist sentiments. Xinjiang, the aforementioned "new frontier” acquired by the Qing dynasty, is rich in oil and gas reserves. After the government launched the Great Western Development program in 1999 to develop the region, it is emerging as a key contributor of China’s energy needs:

According to the preliminary plans of CNPC and Sinopec, the region's oil and natural gas output will hit 30 million tons and 18 billion cubic meters, respectively, by 2010. Combined with the 20 million tons of crude oil imported from Kazakhstan via pipelines, Xinjiang will become the country's largest oil and gas supply base by then. ${ }^{35}$

China's indigenous Uyghur Turkic Muslims live in the Xinjiang Uyghur Autonomous Region where the Han population has grown larger than the indigenous one, ${ }^{36}$ and where separatists have used violence toward their goal of East Turkistan independence. It is worth emphasizing that Ankara has no interest in supporting an independent East Turkistan but, as noted above, it is only within the realm of speculation as to whether Beijing will recognize an independent Kurdistan if it should eventuate. The 2008 Georgian experience suggests that China does not favor the partition of nations, for obvious reasons that such actions may encourage China's own separatists. Despite the

\footnotetext{
33 McElroy, “China Clinches First Iraq Oil Deal”.

34 Ibid.

35 Asia Pulse/XIC, “Oil Focus Shifting to Xinjiang”, Asian Times Online, 10 September 2005, http://www.atimes.com/atimes/China/GI 10Ad05.html, accessed 25.10.07.

${ }^{36}$ Han Chinese form 55\% of Xinjiang's 20 million people, with 45\% being 'ethnic minorities'.
} 
importance of its relations with Moscow, Beijing still expressed concern after Russia signed a declaration recognizing South Ossetia and Abkhazia as independent from Georgia.

Thus the divisions between China and Turkey are more nuanced, more in the nature of potentiality than reality. China's recognition of the Republic of Cyprus rather than the Turkish Republic of Northern Cyprus is hardly exceptional, and would not compare with the fraught situation of recognition or otherwise of the Republic of China on Taiwan. ${ }^{37}$ So this is an improbable issue of dispute. An interview in 2007 by Ankara's International Strategic Research Organization of Atilla Sandikli - Turkish author, former TASAM general manager and retired senior colonel - sheds further light on sensitivities that could spur frosty relations. According to Sandikli:

It is natural that each country looks at foreign policy issues according to its own interests. There are Uyghur Turks there [in China], they are our brothers with common cultural and historical backgrounds. Coming from its historical and cultural depth, it is a mission for Turkey to give voice to problems of Uyghur Turks and although this disturbs China, it is not possible to completely eliminate this. So, are we not going to improve our relations on the basis of this problem? [Such stagnation] is out of question. We need to develop our relations with China. China also follows some similar policy elements. It develops relations with Turkey's neighbors, with countries like Iraq. Of course, it also has some relations with the Iraqi Kurds' region. Also, in the Southern Cyprus governance region it has relations. The important thing here [for PRC foreign policy] is not to exceed legitimate levels and not to move together [with other parties] directly against Turkey. Such relationships would certainly disturb us. It would be very disturbing for us to see a country like China, which is growing in global stature, to directly contact these regions and to see that there are sometimes some comments which seem unfavorable to Turkey ... I think Turkey, too, has become more experienced about handling the Uyghur issue. China, as well, will have significant experience in understanding issues that disturb Turkey. It is to be expected that in the future the relationship will be less prone to such sensitivities. ${ }^{38}$

\footnotetext{
${ }^{37}$ See Yuksel Soylemez, “The Question of Cyprus and the Question of Taiwan: A Comparison”, n.d., http://www. ceeol.com/aspx/getdocument. aspx?logid =5\&id=afc206bf-7a2a-47b0-bafd19fea88cd267, accessed 30.12.07.

${ }^{38}$ Arilla Sandikli, “The Foreign Policy Principles of Turkey and China Match Well”, USAK [International Strategic Research Organization (ISRO - USAK) www. usak. org.tr] Turkey-China Relations Interview Series - II. Interview by Eyüp Ersoy, 20 September 2007. Trans. Nadir Kemal Yilmaz.
} 
What is to be done? If economic relations are the vanguard of Sino-Turkish diplomacy then it is in this arena that progress may be pursued in the first instance through greater diversification of trade sectors and investing into each other's markets. It could well be that other sectors are also best dealt with by expanding the horizon. This relates back to Eurasia as a constructivist cause: a region of mutually constitutive relationships.

\section{Beyond the Great Wall}

When looking at the Eurasian expanse with its Central Asian centre and emerging power periphery, one feature stands out. Snaking across its normative heartland, like the curve separating - and connecting - yin and yang, is the Great Wall. This iconic fortification was built across centuries of Chinese history to protect the northern borders against raids by Mongol, Turkic and other tribes of Central Asia. Its continued construction only ceased when China under a Manchu dynasty, the Qing, expanded its territory beyond the Great Wall into Mongolia. In other words, it took foreign influence for China to outgrow its Great Wall mentality, and then by means of absorbing the lands beyond the Wall into China. Maintaining such a vast domain required a Confucian-trained bureaucracy and a concomitant strategic culture which preferred diplomatic over military solutions to state insecurity. ${ }^{39}$ Ultimately, therefore, China needed to "trust in virtue, not walls" ${ }^{40}$ to succeed. While it might be argued that the People's Republic has embarked on an expansionist drive into Central Asia to assure itself of energy security, it could equally (and more plausibly) be said that the solution to China's energy and security problems (such as ethnic separatism) may be found through diplomatic cooperation. This is where region-building mechanisms come into play, particularly the Shanghai Cooperation Organization.

Indeed, Beijing's attempt to limit the danger of separatist behavior among its Uyghur population has been credited with being the inspiration for the SCO. "This was the key reason,"

39 This is elaborated in Rosita Dellios, “Chinese Strategic Culture - Part 1: The Heritage from the Past”, Research Paper No. 1, Centre for East-West Cultural and Economic Studies (CEWCES), Bond University, April 1994; and Rosita Dellios, "Chinese Strategic Culture - Part 2: Virtue and Power", Research Paper No. 2, CEWECS, November 1994. Both are available at Dellios' personal researcher page: http://epublications.bond.edu.au/rosita_dellios/, and the website www.international-relations.com.

${ }^{40}$ Attributed to a Chinese minister, AD 280. 
Fuller and Starr argue, “for China’s establishment in 1996 of the Shanghai group as a forum where regional security issues could be discussed . . "41 Border issues, however, provided the impetus for the organization's activation. The SCO was originally formed in 1996 as the "Shanghai Five" comprising China, Russia, Kazakhstan, Kyrgyzstan, and Tajikistan - to demilitarize the old SinoSoviet border and resolve border demarcation disputes. The “Shanghai Five” became the Shanghai Cooperation Organization in July 2001 with the addition of Uzbekistan. In 1999 "Islamic fundamentalism” was seen as the most pressing danger for Central Asian governments; fighting "terrorism, separatism and extremism" came to dominate the agenda. This certainly links to China's Uyghur problem but the SCO has evolved to specialize in "multifaceted political, economic and cultural cooperation". ${ }^{42}$ For example, cross-border drugs crime is also targeted by SCO and a development fund is being considered. This takes it beyond a straightforward counterterrorism function and brings it into multilateral regionalism of the type that could represent a distinctive Eurasian international order - but "under the auspices of the UN”, as SCO SecretaryGeneral Bolat Nurgaliev insists. ${ }^{43}$ The UN's role was emphasized at the 2007 SCO Bishkek summit in "laying out the member states’ vision for a new international security architecture”, ${ }^{4}$

The geopolitical contours of this emergent regionalism and its security architecture may suggest that while the Uyghur problem could have been uppermost in Chinese minds with regard to establishing the SCO, as well as the new states of Central Asia fearing the spread of Islamic fundamentalism, there is also another motive attributed as the raison d'etre of the SCO: strategic denial of US power into energy-rich Eurasia and the possibility of close proximity to the Russian and Chinese borders. ${ }^{45}$ Even emphasizing SCO's adherence to the UN and its Charter may be interpreted as a criticism of US foreign policy when it disregards the UN, as occurred with the USled invasion of Iraq in 2003. In the SCO's support for a multipolar world resides an implied criticism of US unipolar dominance of the international order. While in declaratory statements the

\footnotetext{
${ }^{41}$ Graham E. Fuller and Frederick S. Starr, “The Xinjiang Problem”, Central Asia Caucasus Institute, The Johns Hopkins University, Baltimore, 2004, p. 43, http://www.cornellcaspian.com/pub2/xinjiang_final.pdf, accessed 5.8.07.

${ }^{42}$ See Shanghai Cooperation Organization (2004-2005), www. sectsco.org/news, accessed 23.10.07.

${ }^{43}$ Bolat Nurgaliev, "Interview of SCO Secretary-General Bolat Nurgaliev with Emerging Markets News Agency", 2007, SCO Website, www. sectsco.org/html/01794. html, accessed 23.10.07.

${ }^{44}$ Ibid.

${ }^{45}$ See, for example, M. K. Bhadrakumar, "SCO is Primed and Ready to Fire", 4 August 2007, Asia Times, www.atimes.com, accessed 18.8.07; and Lili Di Puppo, "The Shanghai Cooperation Organization on the Brink of a New Era?”, 2006, CAUCAZ.COM, www. caucaz.com/home_eng/breve contenu imprim.php?id=252, accessed 8.8.07.
} 
SCO is not a military-political bloc and is not aimed at third parties, its joint military exercises may cause concern to those who fear it is intended as an anti-Western strategic alliance, with implicit strategic opposition to NATO. Indeed, SCO has been described as "a Sino-Russian platform to hedge against America’s expansion into Central Asia after the September 11 attack”. ${ }^{46}$ On the other hand, SCO Secretary-General Bolat Nurgaliev has drawn attention to the fact that the "SCO and NATO have shared concerns in fighting terrorism, drugs trafficking, as well as stabilizing the situation in Afghanistan”. 47

With progress in Afghanistan still being hindered by resistance from the Taliban, a decline in economic growth and high levels of opium production, accounting for 93\% of the world's production, ${ }^{48}$ a united approach by NATO and SCO is even more compelling. Importantly, SCO regards itself as an open organization and as the Bishkek Declaration states, it "is open for interaction with all interested partners based on international law and generally accepted norms of international relations”. ${ }^{49}$ In this light, an SCO-NATO mechanism deserves serious attention.

Fighting under NATO command would pose a problem for a number of SCO members, including China, a situation that could be circumvented if they were under United Nations command instead. But for this to occur, greater UN-NATO cooperation would be needed. ${ }^{50}$ On a lesser scale of expectations, an SCO-derived boost in the UN police presence in Afghanistan would help in that Afghanistan represents a greater vital interest to SCO countries than, say, the Middle East. Compared to the approximately 1000 Chinese peacekeepers serving in United Nations Interim Force in Lebanon (UNIFIL), China has only one police officer on a UN Peacekeeping mission in Afghanistan. Given that Afghanistan and China (at Xinjiang) share a common border of 75 kilometers, a greater presence would be expected. Moreover, Afghanistan and its border with Pakistan represent the spiritual heartland of Islamic fundamentalism and is therefore of concern to all SCO members. In a sense, SCO's gradual enlargement through “observer” status and partnership links (including Afghanistan - see below) also prove advantageous. They represent a

\footnotetext{
${ }^{46}$ Jing Huang, "Beijing's Perspectives on the Russo-Georgian Conflict: Dilemma and Choices”, China Brief, Vol. 8, Issue 17, 3 September 2008, http://www.jamestown.org/china_brief/article.php?articleid=2374389, accessed 14.9.08.

${ }^{47}$ Nurgaliev, "Interview of SCO Secretary-General Bolat Nurgaliev with Emerging Markets News Agency".

${ }^{48}$ UN findings cited in James G. Neuger, “NATO Staggers in Afghanistan”, Turkish Daily News, 9 October 2007, p. 6.

${ }^{49}$ Bishkek Declaration, 2007, www. sectsco.org/news, accessed 23.10.07.

${ }^{50}$ See “Debate: Should NATO Support UN Peacekeeping Operations?”, NATO Review, Summer 2005, http:// www. nato.int/docu/review/2005/issue2/english/debate. html, accessed 11.11.07
} 
geostrategic and diplomatic encirclement of the Afghan problem, while laying the foundations for cooperation on a broader scale. In the next section, SCO's modes of expansion are considered, and thence the significance of Sino-Turkish relations.

\section{SCO’s Modes of Expansion}

India, Pakistan and Iran joined as SCO observers in 2005, and Mongolia in 2004. This has expanded SCO’s regional range to South Asia and the Middle East. Observer status is not confined to interested states but may also extend to intergovernmental international organizations. ${ }^{51}$ In the integration of new states or organizations, a "dialogue partner" mechanism is being introduced, thereby allowing for an earlier stage to observer status and fully fledged member. Concern that expansion of SCO would import rivalries has not been demonstrated in view of India and Pakistan being admitted as observers. Nor are great-power/small-power discrepancies necessarily a problem. Despite Uzbekistan’s reported opposition to “quick enlargement of SCO because its voice might be offset by an incoming big constituent power", 52 in many ways the current composition of SCO demonstrates an ability to live with power discrepancies. Iwashita has noted SCO's “complex double structure" of Sino-Russian great power bipolarity and "an asymmetric Central Asian influence (middle power Uzbekistan versus Kazakhstan, Kyrgystan and Tajikistan)”. ${ }^{53}$ Confirming the effectiveness of SCO as a cooperative organization was the reaction of the SCO summit in the Tajik capital of Dushanbe that occurred after the Russo-Georgian conflict. The SCO members, including Russia, declared in a joint statement:

In the 21st century interdependence of states has grown sharply, security and development are becoming inseparable. None of the modern international problems can be settled by force, the role of force factor in global and regional politics is diminishing objectively.

\footnotetext{
51 See "Regulations on Observer Status at Shanghai Cooperation Organization”, 2004-2005, www. sectsco.org/news, accessed 23.10.07.

${ }^{52}$ BBC Monitoring, 28 May 2003, cited in Akihiro Iwashita, "Shanghai Cooperation Organization and Its Implications for Eurasian Security: A New Dimension of ‘Partnership’ after the Post-Cold War Period”, in Shinichiro Tabata and Akihiro Iwashita (eds), Slavic Eurasia's Integration into the World Economy and Community, Slavic Research Center, Hokkaido University, Sapporo, 2004, pp. 278, available at http: //src-

h.slav.hokudai.ac.jp/coe21/publish/no2 ses/4-1 I washita.pdf, accessed 20.7.07.

${ }^{53}$ Ibid., 260.
} 
Reliance on a solution based solely on the use of force faces no prospects, it hinders comprehensive settlement of local conflicts; effective resolution of existing problems can be possible only with due regard for the interests of all parties, through their involvement in a process of negotiations, not through isolation. Attempts to strengthen one's own security to the prejudice of security of others do not assist the maintenance of global security and stability. ${ }^{54}$

This example of avoidance of hierarchical relations through consensus decision-making is a common attribute of Asia-Pacific regionalism, notably evident in the Association of Southeast Asian Nations (ASEAN) which includes a nation as small in power as Laos as well as the more powerful states of Singapore, Thailand and Indonesia; ASEAN+3 (the three being China, Japan, and South Korea); East Asia Summit (comprising ASEAN+3, plus India, Australia and New Zealand), and even the Asia-Pacific Economic Cooperation (APEC) forum that includes not only Asian countries but those from the Americas, including the US, and also Russia. China has deliberately favored structuring its relations with ASEAN in such a way as to retain ASEAN as the centerpiece, especially in the new East Asian regionalism which is an enlarged version of $A S E A N+3$. If China were to place itself in the lead, this would incite rivalry with Japan for East Asian leadership. Similarly in SCO, Russo-Chinese rivalry could be offset by the "balance of interests”55 approach and the integration of the region across many sectors, as shown by development of SCO as a security, economic and socio-cultural region. ${ }^{56}$ The attraction of powerful states or organizations to SCO may well be inevitable in view of Eurasia's strategic importance. However the tiered Asian approach of a core set of states 'plus' other states or organizations is already being formulated in SCO - for example SCO+Afghanistan. ${ }^{57}$ John Lee $^{5}$ notes in a 2008 article that SCO has more in common with ASEAN than the former Warsaw Pact or NATO:

\footnotetext{
${ }^{54}$ Dushanbe Declaration, 2008, http://www.sectsco.org/news_detail.asp?id=2360\&Languagel D=2, accessed 18.9.08.

${ }_{55}^{55}$ Nurgaliev, "Interview of SCO Secretary-General Bolat Nurgaliev with Emerging Markets News Agency".

${ }^{56}$ This tripartite arrangement may be nascent and subject to change as it develops. However, it has been formalized in the much older organization of ASEAN, which began in 1967, and which may be seen as a forerunner in the Asian sphere. Progress on an ASEAN Community - comprising a security community, an economic community and a sociocultural community -became evident in Bali Concord II (Declaration of ASEAN Concord II) adopted by ASEAN leaders at their Summit in Bali, in October 2003. It stressed shared responsibility, shared prosperity and shared identity (Declaration of ASEAN Concord II 2003). See also R. James Ferguson, "ASEAN Concord II: Policy Prospects for Participant Regional 'Development”', Contemporary Southeast Asia, Vol. 26, No. 3, December 2004, pp. 393-416.

${ }^{57}$ Personal communication, November 2007, Shanghai, with Center for Shanghai Cooperation Organization (SCO) Studies within the Shanghai Academy of Social Sciences at www. coscos. org.cn.
} 
Like ASEAN, the SCO accommodates conflicts between external alignments through minimal institutionalization. It lacks a joint military headquarters, collective defense article or any other feature of a NATO-like alliance. The SCO’s only security institution is the Regional Antiterrorism Structure (RATS), whose activities are apparently confined to sharing intelligence on domestic threats. $^{58}$

He also notes that SCO's functional engagement approach is evident in ASEAN having signed a cooperation agreement with SCO in 2005, while the EU is looking at an 'ad hoc dialogue' and similar arrangements are being considered for NATO. ${ }^{59}$

China is undoubtedly a driving force in regional engagement but it is not a dominant force, just as Russia did not interfere with SCO’s 2008 declaration calling for negotiation rather than force in dispute resolution. China is now engaged in multilateral activities that include over 30 cooperation mechanisms in Asia. Sub-regional cooperation has been most active (for example, SCO and ASEAN+3). Transregional cooperation is gaining strength (for example, APEC and the Asia-Europe Meetings-ASEM). Economic regionalism remains China's priority. In the past decade, 24 new arrangements have been concluded. Cooperation in other sectors is expanding, including finance, agriculture, and forestry. Cooperation in security is beginning, notably in the ASEAN Regional Forum (ARF). China-ASEAN relations have developed practical governance in non-traditional security issues. ${ }^{60}$ This bodes well for multilateral cooperative relations spanning Eurasia and into the Middle East. Turkey has already diversified its regional focus in the post-Cold War era. While relations between China and Turkey may appear to be asymmetrical in terms of power and economic weight, they show a distinctive symmetry in their yin-yang relations of geographic location, strategic alignment, and cultural traditions. Moreover, they are both strong states with moderate foreign policies and internal development and security goals to pursue. ${ }^{61}$ This commonality provides common ground for closer ties as long as differences can be integrated into the larger picture.

\footnotetext{
58 John Lee, “The Shanghai Cooperation Organisation: An Australian Response”, Policy Analysis 21, Australian Strategic Policy Institute, 6 March 2008, available at www.aspi.org.au/publications/publicationlist. aspx? pubtype=9, accessed 19.4.08. 59 Ibid.

${ }^{60}$ Yang Yanyi, Deputy Director General, Asian Department, Ministry of Foreign Affairs, PRC, speaking at a seminar attended by Rosita Dellios at China Foreign Affairs University, Beijing, 25 June 2008.

${ }^{61}$ See Dellios and Yilmaz, "Turkey and China: A Study in Symmetry”.
} 


\section{Conclusion}

Flexibility and informality are the hallmark of a globalizing Asia-Pacific, as regional cooperation has tended to start with informal dialogue and then progressed to practical projects. There is also an emphasis on process rather than results. This is in accordance with Confucian cultural dynamics. For example, in the East Asian summit, the "comfort level principle” exists progress may be slow but process ensures it is sustainable. Another feature of China's governance diplomacy is that it prefers to see small and medium size countries taking the lead, not itself. Here a role for Turkey is clearly evident as it is not a hegemonically-driven power.

It cannot be denied that there are obstacles to the furtherance of Sino-Turkish relations within a regional framework for achieving greater interaction for security and economic growth. These include the diversity of cultures and religions in Eurasia, as this poses a problem for identity. On the other hand there is strength in global civilizational dialogue, as demonstrated by the historic Silk Road trading region. A second obstacle is the geographic enormity of the region and its uneven economic development. While presenting a hindrance to greater coordination it also makes it imperative for the rising powers of Asia and Eurasia - China, India, and Russia, in particular - to

ensure stability far from home: their interests, like time and space, have been reconfigured by globalization. Thus strategic interests follow economic interests to unexpected places. For example, China would not have been so concerned with Russian behaviour in the Caucasus before its global interests had developed. A third obstacle concerns mutual confidence which is on occasion undermined by historical legacies or current conflict of interests. Still, regionalism through various multilateral governance regimes - especially an expanding SCO in which Turkey has shown interest in joining - is probable when considered from a multi-track, multi-speed, and multiinstitutional perspective. China and Turkey exhibit a realistic appreciation of the complexity and magnitude of maintaining good relations in their multiregional peripheries. This includes China's awareness of the need to be cautious not to be seen as manipulative of others in view of its size and influence; hence the utility of its "win-win” soft power strategy. Turkey, too, needs to maintain its unique bridging potential between its Western allies and the Middle East, and between its anticipated European future and its Central Asian history. 
In the final analysis it is up to China as the new global power of the $21^{\text {st }}$ century to inspire confidence in overcoming obstacles and promoting the benefits of regional cooperation. China has participated in a range of multilateral organizations and advocates a layered regional cooperation in its governance diplomacy. If China's behavior is to help determine whether the region has an "open, transparent and mutually beneficial future" or "risk blundering into a future where competition and exclusion set the pattern”, as US Defense Secretary Robert Gates said in May 2008 , ${ }^{62}$ then it is apparent that Beijing will need to continue to engage seriously with all players and organizations, including those of which it has tended to be wary or kept its distance in the past. In this respect, relations with important NATO members like Turkey are of contemporary importance. It remains to be seen whether Beijing's proverbial "win-win" formula will fuel the anticipated benefits of greater regional integration. Critics may argue that instead of mutual benefit, China is in fact operating a "zero-sum" game. As identified by poliheuristic theory, "Western rationality" is not always optimal in analyzing the motives of countries of non-Western thought systems. Rather, the relationship with which they engage is mutually-constitutive. Correlative relationships are a feature of East Asian security thinking. This paper has shown that the philosophical underpinnings of China's and Turkey's culture allow for them to move forward towards regional-based relations molded by global flows.

\footnotetext{
${ }^{62}$ Robert Gates, US Secretary of Defense, "Challenges to Stability in the Asia-Pacific", the $7^{\text {th }}$ IISS Asia Security Summit Shangri-La Dialogue, Singapore, 31 May 2008, http://www.iiss. org/conferences/the-shangri-ladialogue/plenary-session-speeches-2008/, accessed 1.10.08. It should be noted that Gates did not name China directly as being a key determining player, but "Pentagon aides said later the comments were directed solely at China, part of a deliberately low-key approach designed to avoid ratcheting up tensions with Beijing” (Yochi J. Dreazen, “U.S. Sounds Caution On China's Diplomacy”, The Wall Street Journal, 31 May 2008, http://online.wsj.com/article/SB121218708981834007.html?mod=googlenews_wsj, accessed 1.10.08).
} 